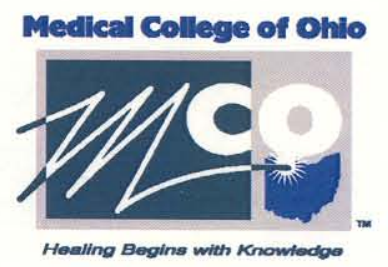

Graduate School

Knowledge Begins with Research

\title{
GRP78/BiP is Involved in Ouabain-induced Endocytosis of the Na/K-ATPase in LLC-PK1 Cells
}

\author{
Submitted by
}

\section{Riad Kesiry}

In partial fulfillment of the requirements for the degree of Master of Science in Biomedical Sciences

\section{$\underline{\text { Examination Committee }}$}

Joseph Shapiro, M.D.

(Major Advisor)

Jiang Liu, Ph.D.

Zi-Jian Xie, Ph.D.

\section{Dean of the Graduate School}

Keith K. Schlender, Ph.D.
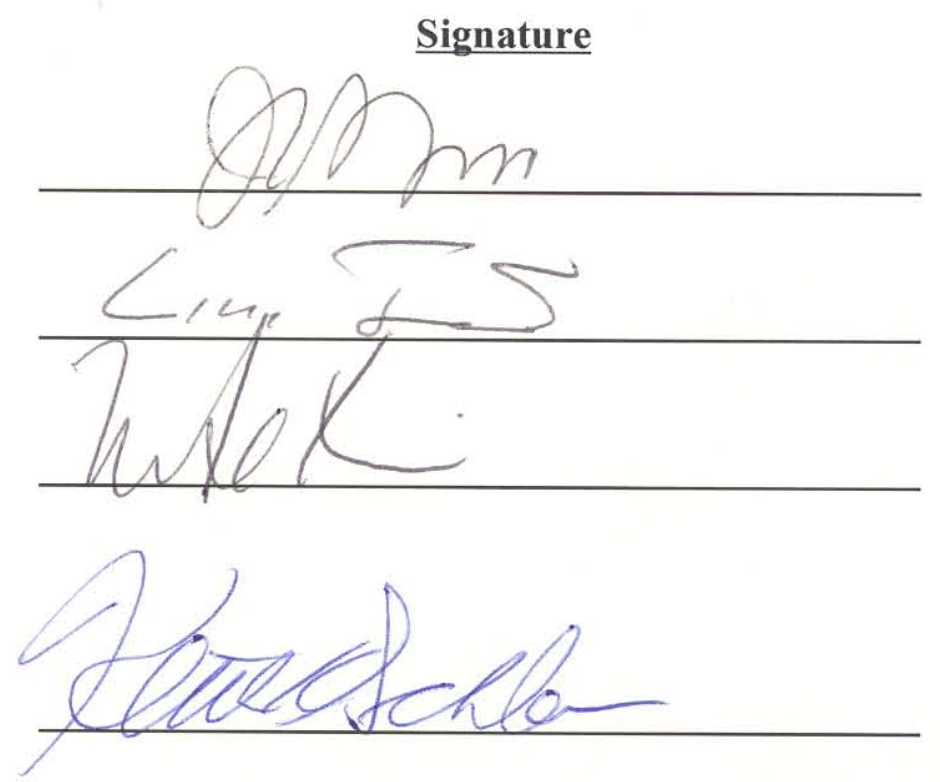

Date of Defense: June 25, 2004 


\section{GRP78/BiP is Involved in Ouabain-induced Endocytosis of the Na/K-ATPase in LLC-PK1 Cells}

\section{Riad Kesiry}

\section{Medical College of Ohio}

2004 


\section{ACKNOWLEDGEMENTS}

I would sincerely like to thank my major advisor Dr. Joseph Shapiro. I truly admire his dedication and hard work. He is a prime example of the tireless devotion necessary to be such an outstanding mentor and teacher for the entire lab. His commitment and dedication have made, and will continue to make, a tremendous difference in the lives of many students.

I would like to thank Dr. Jiang Liu for his excellent assistance. 


\section{Table of Contents:}

ACKNOWLEDGEMENTS ..................................... ii

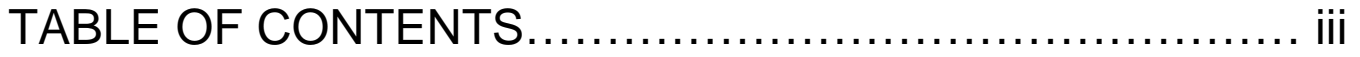

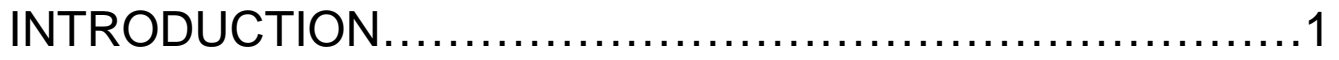

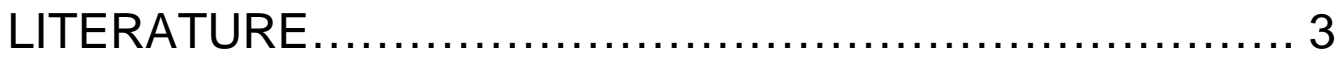

MATERIALS AND METHODS............................... 7

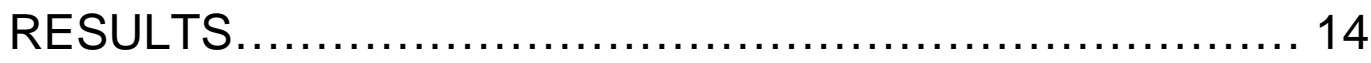

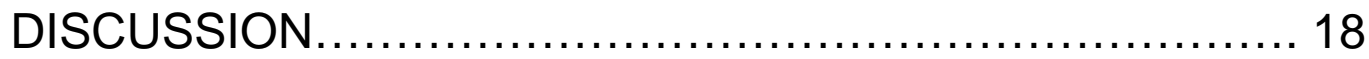

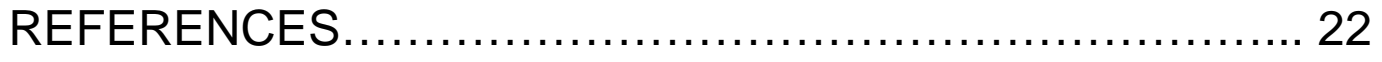

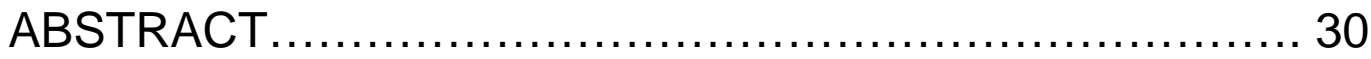




\section{INTRODUCTION}

$\mathrm{Na} / \mathrm{K}-\mathrm{ATPase}$, or sodium pump, is a ubiquitous plasma membrane enzyme that belongs to the family of P-type ATPases and consists of two noncovalently linked alpha and beta subunits (Sweadner 1989; Lingrel et al., 1994). The a-1 subunit, the catalytic subunit, is required for the assembly of the functional enzyme. Recently, we observed that digitals like substances (DLS) or ouabain induces redistribution of Na/K-ATPase within LLC PK1 cells and ouabain treatment on basolateral side caused a dose and time dependent decrease in a-1 subunit of the Na/K-ATPase (Liu et al., 2002; Liu et al., 2004). We also demonstrated that ouabain induces endocytosis of the a-1subunit of $\mathrm{Na} / \mathrm{K}$ ATPase and mediated by clathrin-dependent pathway.

In this study, our approach is based on two-dimensional (2D) gel electrophoresis and liquid chromatography-tandem mass spectrometry (LCtandem MS) to identify proteins which are possibly involved in ouabain induced endocytosis in LLC PK1 cells. Using this technique allowed us the separation of complex mixtures of proteins into individual components. We started with analyzing endosome proteins from control and ouabain treated cells. Several proteins were identified by mass spectrometry and one of the proteins that showed high level of up regulation in ouabain treated cells was a $78 \mathrm{kDa}$ Glucose-Regulated Protein (GRP78), also called immunoglobulin heavy chain binding protein $(\mathrm{BiP})$. This Interesting finding confirmed by western blots that determine protein expression by using a specific antibody to bind to the concerned protein. 
GRP78/BiP protein is of interest for several reasons: GRP78/BiP is involved in the structural and functional maturation of the Na/K- ATPase (Beggah, et al., 1996; Jorgensen 2003), this protein is essential for the proper folding and assembly of many newly synthesized secretory and membrane proteins (Haas 1994; Mote et al., 1998), its critical role for maintenance of cell homeostasis and prevention of apoptosis (Liu et al., 1997; Yang et al., 2000; Rao et al., 2002) and as a model protein induced following a variety of cell stress conditions (Lee 2001). 


\section{LITERATURE}

A GRP78 also known as BiP or immunoglobulin heavy chain binding protein (Haas and Wabl 1983), is a stress protein and a member of the $70 \mathrm{kDa}$ heat shock proteins family (HSP70). A GRP78/BIP is a resident protein of the endoplasmic reticulum (ER) and acts as a molecular chaperone (Ellis et al., 1989). This protein associates with a variety of newly synthesized secretory and membrane proteins, binds with misfolded or defective proteins preventing their export from the ER lumen (Gething 1999). As a result assisting proper folding and assembly of oligomeric secretory proteins (Beguin et al., 2000). The GRP78/BIP levels are critical and determine level of many membrane and secreted proteins. In eukaryotic cells, most secretory and membrane proteins enter into the endoplasmic reticulum (ER) lumen on the way to their final destination and GRP78/BIP retains them in a condition fit for proper folding and Oligomerization (Haas 1994).

\section{GRP78/BIP and Na/K-ATPase}

Most of the a-1 subunit of Na/K-ATPase set in within the plasma membrane with less of the molecule ( 10\%) exposed to the ER lumen. The residues ${ }^{868}$ ENGFLIPIHLL ${ }^{878}$ in the L7 8 loop of Na/K-ATPase a-1 subunit exposed to the ER lumen represent definitely GRP78/BIP binding place (Jorgensen et al., 2003). The same loop is in charge for the alpha and beta associations which is necessary for leaving the ER lumen (Beguin et al., 2000). The type II glycoprotein $\beta$ subunit of $\mathrm{Na/K}-\mathrm{ATP}$ ase has been found to influence the structural and functional maturation of the $\alpha$-subunit and to smooth the progress of the 
passage of $\mathrm{Na/K}-\mathrm{ATP}$ ase to the plasma membrane(Eakle et al., 1995). In Xenopus oocytes, different research groups have studied GRP78/BIP and its

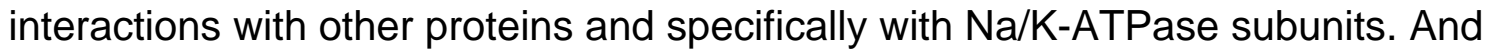
they showed that the $\mathrm{Na} / \mathrm{K}-\mathrm{ATPase}$ a-1 subunit cannot mature and be translocated to the plasma membrane without the assembly with B-subunit which is necessary for the conformational maturation. The binding of $\mathrm{BiP}$ with the catalytic $\alpha$-subunit of Na/K-ATPase lasts until subunit assembly (Beggah et al., 1996; Beguin et al., 1998, 2000).

\section{GRP78/BIP and the Cell Surface}

Recently, many studies in rat pancreatic cells (Takemoto et al., 1992), in Meth A sarcoma cells (Altmeyer et al., 1996), in immature thymocytes (Wiest et al., 1997) and in NG108-15 cell (Xiao et al., 1999) provide evidence that GRP78/BIP is not only located inside the ER, but also exists on the cell surface. And GRP78/BIP with other stress proteins such as GRP60, GRP70, GRP90 can be expressed on cell surface either consecutively or following stress induction. This finding is unexpected since GRP78/BIP is a soluble ER protein, and GRP78/BIP contains a highly conserved sequence (KDEL) which is present at C terminus of GRP78/BIP.

The presence of carboxy terminal KDEL is necessary for preventing the export of misfolded and defected proteins from the ER lumen. This retention mediated by means of KDEL Receptor (Munro and Pelham 1987). Several studies have proposed possible functions of the presence of some ER proteins 
on cell surface. The most interesting explanation for presence of KDEL proteins on cell surface of different cells is related to the ability to associate to other proteins, particularly with high molecular weight complexes proteins (Xiao et al., 1999; Delpino and Castelli, 2002)

\section{GRP78/BIP and Calcium}

In addition to the "molecular chaperone" function, GRP78/BIP is also known to have Ca binding functions. The depletion of intracellular Ca stores by the calcium ionophore A23187 and thapsigargin (SERCA-2B activity inhibitor) increases grp78/BIP expression (Li et al., 1993).The increased GRP78/BiP expression may be crucial in preventing cells damage and death in the ER (Villa et al., 1991).

\section{GRP78/BIP and ER Stress-induced Cell Death}

In general, ER stresses (changes in $\mathrm{Ca}^{2+}$ homeostasis, accumulation of misfolded proteins in the ER and underglycosylated proteins) increase the GRP/BIP gene expression. Prolonged ER stress may cause cell death, and GRP78/BIP has protective role in preventing ER stress-induced cell death (Rao et al., 2002).

The cellular response to ER stress is known as the Unfolded Protein Response (UPR). The UPR is characterized by an increase of the ER resident chaperones including GRP78/BIP and is required to ease ER stress and correct the protein folding process, or, if failed (no GRP induction), prompt programmed cell death (apoptosis). Recently, the Caspase 12 (an ER membrane bound protease) is found to be involved in ER stress-induced cell death, and is a 
essential mediator in this process. The GRP78 inhibits both caspase activation and caspase-mediated apoptosis through forming a complex with caspase 7 and 12 that blocking release caspase12 from the ER (Nakagawa et al., 2000; Rao et al., 2002). 


\section{MATERIALS AND METHODS}

\section{Materials}

Chemicals of the highest purity available were obtained from Sigma (St. Louis, MO). EZ-Kink sulfo-NHS-ss-Biotin and ImmunoPure immobilized streptavidinagarose beads were obtained from Pierce Biotechnology (Rockford, IL). PVDF membranes (Hybound-P) were obtained from Amersham Biosciences (Piscataway, NJ).

polyclonal antibodies against GRP78/BIP were obtained from Affinity BioReagents (Golden, CO). Monoclonal antibodies against GRP78/BIP was from BD Biosciences. Polyclonal and monoclonal antibodies against Na/K-ATPase $\alpha 1$ subunit (clone C464.6). Polyclonal antibodies against Rab5, Rab7, EEA-1 as well as horseradish peroxidase conjugated goat-anti mouse and goat-anti rabbit IgG were from Santa Cruz Biotechnology (Santa Cruz, CA). Monoclonal antibody against $\mathrm{Na} / \mathrm{K}-\mathrm{ATPase} \alpha 1$ subunit (clone $\alpha 6 \mathrm{~F}$ ) were obtained from Hybridoma Bank (University of lowa, lowa City, IA); Alexa Fluor® 488- or Alexa Fluor® ${ }^{\circledR 46-}$ conjugated anti-mouse or anti-rabbit secondary antibodies were obtained from Molecular Probes (Eugene, OR). Normal mouse IgG and rabbit IgG were purchased from Sigma.

\section{Cell Culture}

The LLC-PK1, the pig renal proximal tubule cell line, was obtained from the American Tissue Type Culture Collection (Manassas, VA), and cultured to confluent condition as described before (Liu et al., 2002). Cell viability was evaluated by Trypan blue exclusion and LDH release measurement. In some 
experiments, LLC-PK1 cells were grown as monolayer to confluence (6-7 d). Medium was replaced daily until $12 \mathrm{~h}$ before experiments at which time the monolayer was serum starved as reported previously (Liu et al., 2002). Medium was changed daily until the cells reached $80-90 \%$ confluence at which time the medium was changed to DMEM with FBS for at least $12 \mathrm{~h}$ prior to experiments.

\section{Western Blot}

Proteins were separated by $10 \%$ SDS-PAGE or NuPAGE $4-12 \%$ Bis-Tris gels (Invitrogen), and transferred to PVDF membrane. After transfer, the gel was stained with Coomassie Brilliant Blue to verify uniform loading and transfer. Immunoblotting was performed as described everywhere. Detection was performed using the enhanced chemiluminescence $(E C L)$ super signal kit (Pierce). Multiple exposures were analyzed to assure that the signals were within the linear range of the film. Autoradiograms were scanned with a Bio-Rad GS670 imaging densitometer (Bio-Rad, Hercules, CA) to quantify the signals (Liu et al., 2002).

\section{Immunoprecipitation of $\alpha 1$-subunit of Na/K-ATPase, GRP78/BIP}

Immunoprecipitation of $\alpha 1$-subunit and GRP78/BIP was proceeded mainly as described (Sorkin et al., 1995; Haas et al., 2002; Stoddart et al., 2002). Briefly, after washing (2X) with PBS-Ca-Mg and with PBS, cells were solubilized in TGH buffer (1\% NP-100, 0.25\% sodium deoxycholate, 10\% glycerol, $50 \mathrm{mM} \mathrm{NaCl}, 50$ mM Hepes, pH 7.3, 1 mM EGTA, 1 mM sodium orthovanadate, 1 mM PMSF, 10 $\mu \mathrm{g} / \mathrm{ml}$ leupeptin, $10 \mu \mathrm{g} / \mathrm{ml}$ aprotinin). After brief centrifugation (13,000 $\times \mathrm{g}$ for 15 min), supernatants, containing equal amounts of protein, were 
immunoprecipitated with a saturating amount of antibodies against $\alpha 1$ subunit or GRP78/BIP at $4^{\circ} \mathrm{C}$ overnight with end-to-end rotation, and then $2 \mathrm{~h}$ with Protein $\mathrm{A}$ or G-agarose beads (Upstate). Immunoprecipitates were washed (2X) with TGH and with PBS. Proteins were eluted with (2X) lammli sample loading buffer and resolved on SDS-PAGE followed by immunoblotting. Normal rabbit or mouse IgG was used for as a control.

\section{Preparation of Endosomes}

Endosomes were fractionated on a flotation gradient using the technique of Gorvel et al (1991). Briefly, control and treated cells were washed twice with icecold PBS-Ca-Mg (PBS containing $100 \mathrm{uM} \mathrm{CaCl} 2$ and $1 \mathrm{mM} \mathrm{MgCl}_{2}$ ) and once with ice-cold PBS. The cells were collected in PBS and centrifuged for 5 min at $4^{\circ} \mathrm{C}$ and 3,000 $\mathrm{x}$. The pellet was re-suspended in $3 \mathrm{ml}$ of the homogenization buffer (250 mM sucrose in $3 \mathrm{mM}$ imidazole, $\mathrm{pH}$ 7.4) and re-centrifuged for $10 \mathrm{~min}$ at $4^{\circ} \mathrm{C}$ at $3,000 \times \mathrm{g}$. The pellet was re-suspended in $1.0 \mathrm{ml}$ of homogenization buffer (with $10 \mu \mathrm{g} / \mathrm{ml}$ aprotonin, $10 \mu \mathrm{g} / \mathrm{ml}$ leupeptin, $1 \mathrm{mM}$ PMSF, and $0.5 \mathrm{mM}$ EDTA) and gently homogenized on ice using a Dounce homogenizer (15-20 strokes), followed by a centrifugation ( $10 \mathrm{~min}$ at $4^{\circ} \mathrm{C}$ at $3,000 \times \mathrm{g}$ ). The supernatant was adjusted to $46 \%$ sucrose using a stock solution of $62 \%$ sucrose in $3 \mathrm{mM}$ imidazole ( $\mathrm{pH}$ 7.4) and loaded at the bottom of a centrifuge tube, to which sequentially added $16 \%$ sucrose $(4 \mathrm{ml})$ in $3 \mathrm{mM}$ imidazole and $0.5 \mathrm{mM}$ EDTA in

${ }^{2} \mathrm{H}_{2} \mathrm{O}, 10 \%$ sucrose in the same buffer $(3 \mathrm{ml})$, and finally homogenization buffer (1 ml). The gradient was centrifuged for $60 \mathrm{~min}$ at $4^{\circ} \mathrm{C}$ and $130,000 \times \mathrm{g}$ in a Beckmann SW 40Ti rotor. Early endosomes were collected at the 16\%/10\% 
sucrose interface, whereas the late endosomes were collected at the homogenization buffer and 10\% sucrose interface. The identity of early and late endosomes was determined with polyclonal antibodies raised against Rab5 and Rab7, respectively. Additional confirmation was obtained using EEA-1 which, like Rab 5 was found almost exclusively at the $16 \% / 10 \%$ interface.

\section{TCA Protein Precipitation}

In preparing endosome samples for one or 2D electrophoresis, trichloroacetic acid (TCA) precipitation is used to concentrate proteins. Samples were precipitated by adding equal volumes of ice cold $20 \%$ TCA. The mixture incubated for $30 \mathrm{~min}$ on ice and then centrifuged for $15 \mathrm{~min}$ at 4 degrees. The supernatant was discarded and $300 \mu$; a cold acetone was added to the pellet with spinning for 5 min at 4 degrees. The supernatant was removed and the pellet dried by placing tubes in room temperature for 5-10 min to drive off acetone.

\section{Biotinylation of Cell Surface Exposed Proteins}

Cell surface biotinylation was performed as described above (Gottardi and Caplan 1993; Gottardi et al., 1995; Liu et al., 2002). The LLC-PK1 cells were grown in $35 \mathrm{~mm}$ petri dishes. After three washes with ice-cold PBS-Ca-Mg (PBS containing $100 \mathrm{H}^{\mathrm{mol}} / \mathrm{L} \mathrm{CaCl}$, and $1 \mathrm{mmol} / \mathrm{L} \mathrm{MgCl}$ ), the surface proteins were biotinylated with EZ-Kink sulfo-NHS-ss-Biotin $(1.5 \mathrm{mg} / \mathrm{mL}$ in $10 \mathrm{mmol} / \mathrm{L}$ triethanolamine $\mathrm{pH} 9.0$, containing $2 \mathrm{mmol} / \mathrm{L} \mathrm{CaCl}$ and $150 \mathrm{mmol} / \mathrm{L} \mathrm{NaCl}$ ) for 25 minutes on ice two times. Non-reacted sulfo-NHS-ss-biotin was washed twice with ice-cold PBS-Ca-Mg-glycine (PBS-Ca-Mg containing 100 mmol/L glycine) 
and quenched with the same solution for 20 min on ice to make sure the entire biotinylation reagent was quenched. After two washes with PBS-Ca-Mg, cells were lysed with $1.0 \mathrm{~mL}$ cell lysis buffer $(1 \%$ Triton X-100, $150 \mathrm{mmol} / \mathrm{L} \mathrm{NaCl}, 5$ $\mathrm{mmol} / \mathrm{L}$ EDTA, $50 \mathrm{mmol} / \mathrm{L}$ Tris-HCl, $\mathrm{pH}$ 7.5) for $60 \mathrm{~min}$ on ice. The cell lysates were clarified by sedimentation at $14,000 \times \mathrm{g}$ for $10 \mathrm{~min}$ at $4^{\circ} \mathrm{C}$. Biotinylated proteins were separated with a $50 \%$ slurry of ImmunoPure immobilized streptavidin-agarose beads (Pierce) overnight at $4^{\circ} \mathrm{C}$, with end-to-end rotation. The beads were washed three times with lysis buffer, two times with high-salt washing buffer (0.1\% Triton X-100, $500 \mathrm{mmol} / \mathrm{L} \mathrm{NaCl}, 5.0 \mathrm{mmol} / \mathrm{L}$ EDTA, 50 $\mathrm{mmol} / \mathrm{L}$ Tris-Cl, $\mathrm{pH} 7.5)$, and two times with no-salt washing buffer $(10 \mathrm{mmol} / \mathrm{L}$ Tris- $\mathrm{Cl}, \mathrm{pH}$ 7.5). Proteins bound to the beads were eluted by incubated at $55^{\circ} \mathrm{C}$ water bath for $30 \mathrm{~min}$ in an equal volume of $2 \times$ Laemmli sample buffer. Proteins then were applied to SDS-PAGE and Western blot as described above.

\section{D-gel Electrophoresis}

For 2D gel electrophoresis (2DE), endosomal fraction protein were lysed in a solution containing $40 \mathrm{mM}$ Tris, $8 \mathrm{M}$ urea, 4\% CHAPS, $2 \mathrm{M}$ thiourea, $2 \mathrm{mM}$ TBP, $0.2 \%$ Ampholytes, $0.0002 \%$ bromophenol blue.

Immobilized pH gradient (IPG) gels (11 cm ReadyStrip IPG strips,PH 3-10 NL,Biorad) were rehydrated with the solubilized sample. Isoelectric focusing was performed on Bio-Rad PROTEIN IEF System. Immediately after focussing, IPG gels were equilibrated in $6 \mathrm{M}$ urea, $2 \%$ SDS, $50 \mathrm{mM}$ Tris,pH 6.8 and $30 \%$ glycerol, first with $65 \mathrm{mM}$ DTT for $15 \mathrm{~min}$ then with $135 \mathrm{mM}$ Lodoacetamide for 15 min before running in the second dimension gel electrophoresis $10 \%$ SDS- 
PAGE gels. Gels were stained with Colloidal Blue Staining (Invitrogen), scanned, and analyzed using PDQuest software.

\section{Protein Identification by Mass Spectrometry}

Differential spots were excised from the coomassie stained 2D gels, which showed the highest expression level for each spot. The selected protein spots were destained with $30 \%$ methanol for $3 \mathrm{~h}$ at room temperature and treated overnight with modified, sequencing grade trypsin (Promega, Madison, $\mathrm{WI}$ ) as described previously (Basrur et al., 2003).Briefly, The selected gel spots were covered in $150 \mathrm{ul}$ of $50 \%$ acetonitrile in $0.1 \mathrm{M}$ ammonium bicarbonate buffer, $\mathrm{pH}$ 8.0, for $30 \mathrm{~min}$. Gel spots were cut up into $1 \mathrm{~mm}$ cubes and dried using a vacufuge (Eppendorf). The diced cubes were reswollen in a small volume of 0.1 $\mathrm{M}$ ammonium bicarbonate buffer with trypsin $(0.5 \mathrm{ug})$. The proteins were digested italics for $16 \mathrm{~h}$ at $37 \mathrm{C}$ and new trypsin $(0.25 \mathrm{ug})$ added after $12 \mathrm{~h}$. Peptide fragments were extracted with 150 ul of $60 \%$ acetonitrile containing $0.1 \%$ TFA for 30 min, subsequently with 100 ul of acetonitrile containing $0.1 \%$ TFA. Using Vacufuge all extracts were brought to a final volume of $10 \mathrm{ul}$. Two $\mathrm{ml}$ of the digest was separated on a reverse phase column (Aquasil C18, 15 um tip $\mathrm{x}$ 75 um id x 5 cm Picofrit column, New Objectives, Woburn, MA) using acetonitrile/1\% acetic acid gradient method (5-75\% acetonitrile for 35 min after that $95 \%$ acetonitrile wash for $5 \mathrm{~min}$ ) at a flow rate of $250 \mathrm{nl} / \mathrm{min}$. Peptides were analyzed using an ion-trap mass spectrometer (LCQ-Deca XP Plus, ThermoFinnigan) equipped with a nano-spray supply and operated on double play mode to analyze the positive ions. Dynamic exclusion was performed to pull 
together two collision induced dissociation (CID) spectra on the most abundant ion and then eliminate it for $2 \mathrm{~min}$.

Protein identification was conducted using TurboSEQUEST

(TheormoFinnigan). Results were manually confirmed and any unrevealed CID spectra were searched using the MS-Tag provision of Protein Prospector program(http://prospector.ucsf.edu) or SwissProt database. 


\section{RESULTS}

\section{Proteomic Analysis Identifications}

To identify proteins that are involved in ouabain-induced endocytosis, 2D gel electrophoresis of endosomal fraction is applied. After staining with coomassie we compared 2D gels of early endosomal fraction from control and ouabain treated LLC PK1 cells that we purified according to the previously described protocol. Three major protein spots (Fig. 1) we observed were notably higher in the gel of LLC PK1 cells that treated with ouabain $(50 \mathrm{nM})$ for $2 \mathrm{~h}$. these protein spots were identified by mass Spectrometry.

One protein spot with a molecular weight of $55 \mathrm{KDa}$ matching to ATP synthase beta chain (mitochondrial F1 complex), a protein spot of $50 \mathrm{KDa}$ corresponding to Vimentin, and a protein spot of $70 \mathrm{kDa}$ matching to glucoseregulated protein (GRP78) or called Immunoglobulin heavy chain binding protein (BIP).

\section{Westren Blot Analysis Confirms Detected Endosomal Proteins}

In order to validate our previously revealed proteins by proteomic analysis, we used Western blot and confirmed presence Vimentin and $78 \mathrm{kDa}$ glucoseregulated protein GRP78/BIP in endosomal fraction. And no band was detected by western blot for ATP synthase beta chain (mitochondrial F1 complex) in endosomal fraction. One possible reason is that reactivity of ATP synthase beta chain antibody with pig species has not been confirmed yet. 
(Fig. 1) 2 D Gel Electrophoresis from Early Endosomes Isolated 2 h Following Ouabain Treatment of LLC-PK1 Cells

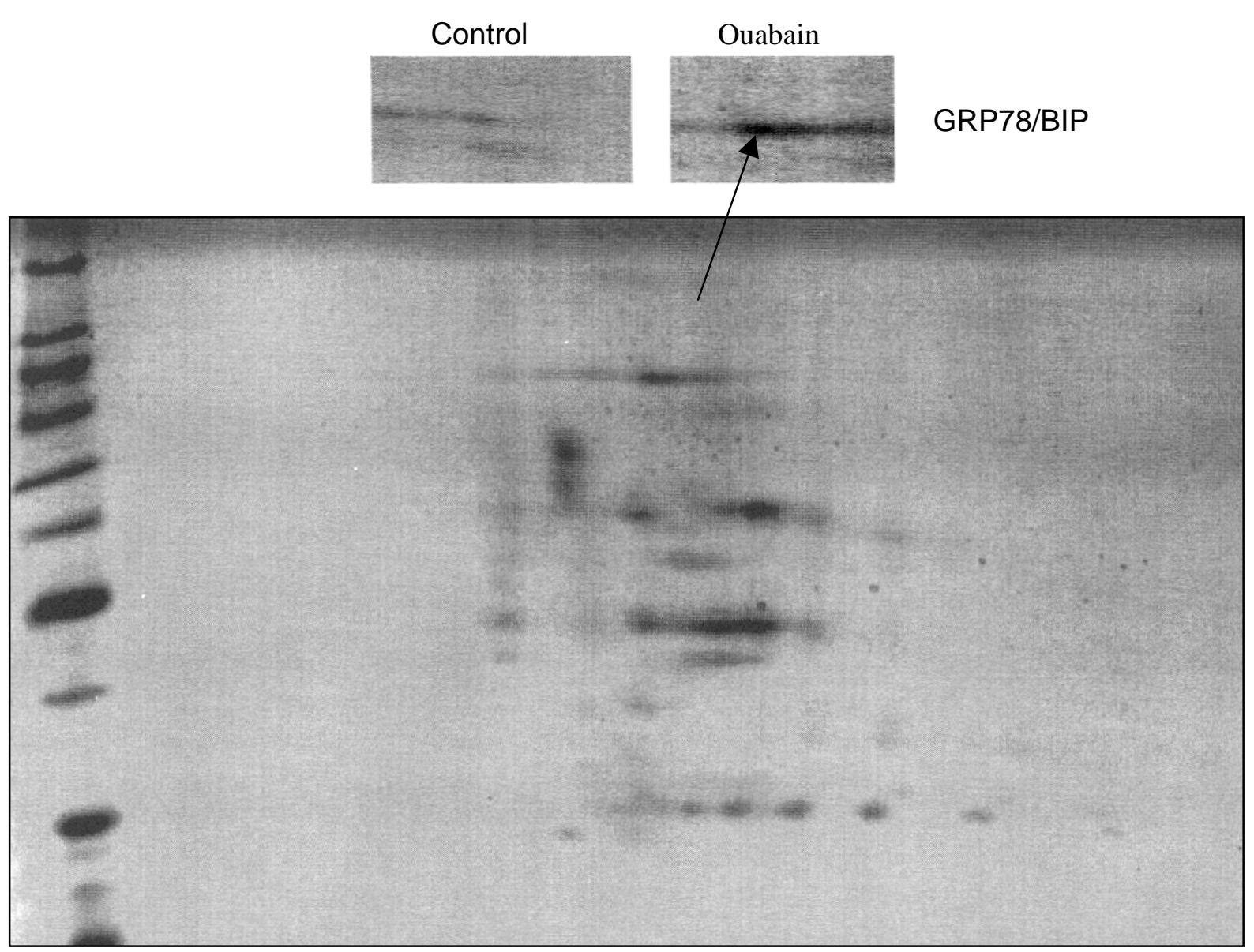

GRP78 Present on the Surface of LLC PK1 Cells

Using the surface bitinylation method, we determined if the GRP78 exist on the surface of LLC PK1. In this experiment we labeled only the surface exposed proteins with NHS-SS-Biotin. The biotin labeled proteins were subsequently isolated by streptavidin/agrose and analysed by SDS-PAGE. Western blot of the biotinylated fraction shows that the GRP78 can be detected in the surface of LLCPK1 cells. 


\section{Ouabain Reduces GRP78 Expression on the Surface of LLC-PK1}

We further determined the level of the surface GRP78 in response to ouabain by measuring biotinylated protein densities. In response to $50 \mathrm{nM}$ ouabain applied to monolayers of LLC-PK1 cells following time course study. We found that biotinylated protein content GRP78 decreased in a time-dependent manner (Fig. 2).

(Fig. 2) Ouabain Reduces GRP78 Expression on The Surface of LLC-PK1 In a Time-dependent Manner

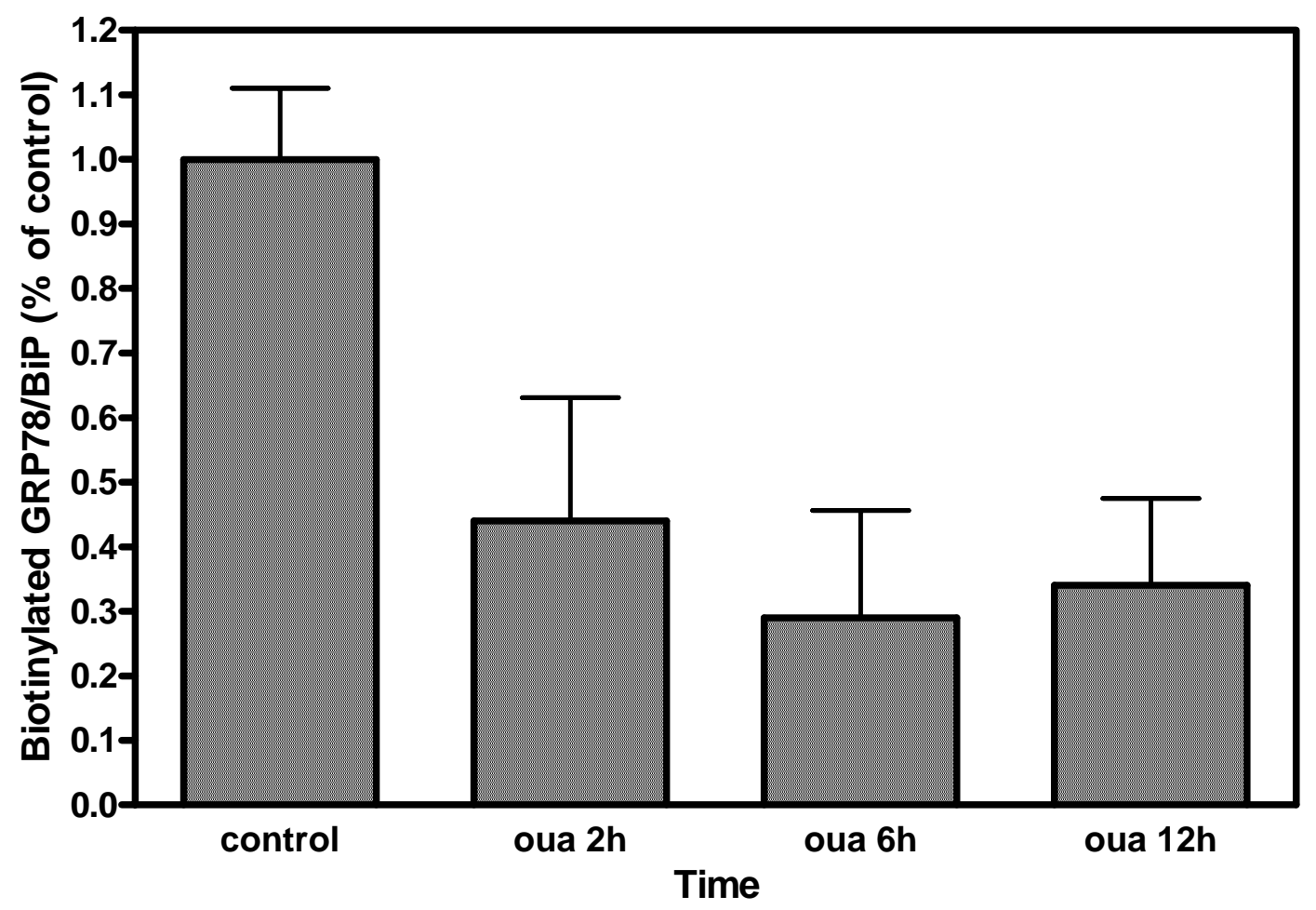


Ouabain Appears to Enhance the Interaction of Na/K-ATPase a-1 with GRP78/BIP

In preliminary experiments performed by applying co-immunoprecipitation of the whole cell lysate with antibodies against the Na/K-ATPase a-1 subunit and GRP78/BiP, we found that ouabain treatment increase the protein-protein interaction between the Na/K-ATPase a-1 subunit and GRP78/BiP. 


\section{DISCUSSION}

\section{Effects of Ouabain on c-fos Expression and GRP 78 /BiP Induction}

Recent studies in vascular smooth muscle cells (VMSC) indicates that ouabain able to induce GRP78/BiP expression (Taurin et al., 2002b). However, the underlining mechanism are not fully understood. In this study we have been investigating the involvment of c-Fos in this effect of ouabain on GRP78/BIP. It is significant that ouabain has been shown and other labs were able to inducing cFos transcriptions in several cell types including hepatocytes (Cayanis et al., 1992), melanoma cells, mouse fibroblasts, HeLa cells (Nakagawa et al., 1992), cardiomyocytes (Peng et al., 1996), mIMCD-3 cells (Joannidis et al. 1997)and thymocytes (Rodrigues Mascarenhas et al., 2003). The increased mRNAs were proportional to the level of inhibition of Na/K-ATPase and the consequential increase in intracellular calcium concentration. In the muscle cells of rats heart an ouabain-induced rise in intracellular calcium causes activation/expression of the transcription factors c-Fos and c-Jun, which together form the transcription factor AP-1(Huang et al., 1997),. Recently, it also was observed that c-Fos expression is induced quickly by ouabain in calciumindependent pathway through increase of $\mathrm{Na} / \mathrm{K}$ ratio and elevation of $\mathrm{Na}$ (Taurin et al., 2002a). Noteworthy, c-Fos (an element of the AP-1 transcription factor complex) is involved in the singling pathway that mediates GRP78/BIP induction following ER calcium release. and that GRP78/BIP induction is prevented by proteasome-mediated c-Fos degradation (He et al., 2000). 
We are proposing that ouabain treatment may induce transcription of genes and one of them encoding c-Fos in so increases AP-1 transcription factor activity and mediates GRP78/BiP induction. More importantly this could explain that inhibition of $\mathrm{Na} / \mathrm{k}$-ATPase by ouabain has anti-apoptosis effect which observed in VSMC (Orlov et al., 1999), LLC-PK1 cells, a pig renal proximal tubular cells(Zhou et al., 2001) and recently in VSMC (Taurin et al., 2002a) Ouabain increases expression of GRP78/BiP, which is well documented, and is protective for the cell against toxicity and apoptosis (Yu et al., 1999; Fernandez et al., 2000; Lee 2001; Rao et al., 2002; Reddy et al., 2003).

Given that GRP78/BiP has been primarily characterized as an ER resident chaperone, we sought to confirm the expression of GRP78 /BiP on the surface of LLC PK1 cells via cell surface biotinlyation to explore further the finding that GRP78/BiP presence in endosome proteins and possible involvement in endocytosis. In agreement with previously published data, the results reported here demonstrate that the presence of GRP78/BiP on the membrane of LLC PK1 cells was confirmed by using the surface biotinylation method followed by Western blot analysis with an anti-GRP78 /BiP antibody. As we examined whether ouabain caused a reduction in surface GRP78 density, interestingly, we found that ouabain treatment caused decreases in the membrane surface GRP78/BIP in time-dependent manner.

This finding is challanging, because all these proteins contain at their carboxyl terminus the KDEL signal sequence, known to function as signal for retention in 
the ER (Munro and Pelham 1987). Our finding that GRP78/BIP can be expressed on the cell surface is in agreement with several previous studies (Altmeyeret al., 1996; Multhoff and Hightower 1996; Berger et al., 1997; Delpino et al., 1998; Xiao et al., 1999; Delpino and Castelli 2002), demonstrating that some ERresident proteins, including GRP78/BIP, GRP96, calreticulin and protein disulfide isomerase, are not completely limited to the ER lumen, but are also expressed on the cell surface either constitutively or following stress induction.

Molecules are transported from the ER in vesicles to the ER-Golgi intermediate compartment and then to the Golgi apparatus ensuing steps in the secretory pathway involving vesicular travel between different compartments from the Golgi to lysosomes or the plasma membrane. But some proteins must be retained within the ER without proceeding along the secretory pathway, particularly GRP78/BIP must be retained within the ER because of the highly conserved sequence Lys-Asp-Glu-Leu (KDEL) which is present at their carboxy terminus of GRP78/BIP. Noteworthy, the KDEL signal does not prevent soluble ER proteins from being packaged into vesicles and carried through the secretory pathway leading from the ER to the cell surface (Cooper, 2000).

The high lipid affinity of GRP78/BIP, and the ability of this chaperone protein to associate with other newly synthesis proteins during the processes of folding, assembly and maturation may explain the translocation of GRP78/BIP to the cell membrane. In addition, these interactions with other proteins might block the KDEL retention signal sequence, allowing GRP78/BIP to leave the ER and to associate with membrane lipidic proteins, in the form of multiprotein 
complexes (Delpino and Castelli 2002). Supporting this hypothesis, it has been found that membrane-exposed GRP78 is indeed tightly associated with many different proteins, forming heterogeneous, high molecular weight, complexes (Xiao et al., 1999).

We previously demonstrated that ouabain induce endocytosis of the $\mathrm{Na} / \mathrm{K}$ ATPase and substantial depletion of the sodium pump density and function on the membrane surface in LLC-PK1 cells (Liu et al., 2002). and that the ouabainstimulated endocytosis of the Na/K-ATPase appears to involve clathrin dependent mechanisms. We are proposing that ouabain could cause a reduction in membrane surface GRP78/BIP by the same mechanism (ouabain-stimulated clathrin dependent endocytosis) which explains why the administration of ouabain also increased the GRP78/BIP content in both early and late endosomes. 


\section{REFERENCES}

Altmeyer, A.; Maki, R.G.; Feldweg, A.M.; Heike, M.; Protopopov, V.P.; Masur, S.K.; and Srivastava, P.K. 1996 Tumor-specific cell surface expression of the-KDEL containing, endoplasmic reticular heat shock protein gp96. Int. J. Cancer, 69(4):340-9.

Basrur, V.; Yang, F.; Kushimoto, T.; Higashimoto, Y.; Yasumoto, K.; Valencia, J.; Muller, J.; Vieira, W.D.; Watabe, H.; Shabanowitz, J.; Hearing, V.J.; Hunt, D.F.; and Appella, E. 2003 Proteomic analysis of early melanosomes: identification of novel melanosomal proteins. J. Proteome Res.,2(1):69-79

Beggah, A.; Mathews, P.; Beguin, P.; and Geering, K. 1996 Degradation and endoplasmic reticulum retention of unassembled alpha- and beta-subunits of $\mathrm{Na}, \mathrm{K}-\mathrm{ATPa}$ a correlate with interaction of BiP. J. Biol. Chem., 271(34):20895-902.

Beguin, P.; Hasler, U.; Beggah, A.; Horisberger, J.D.; and Geering, K. 1998 Membrane integration of $\mathrm{Na}, \mathrm{K}-\mathrm{ATP}$ ase alpha-subunits and beta-subunit assembly. J. Biol. Chem., 273(38):24921 31.

Beguin, P.; Hasler, U.; Staub, O.; and Geering, K. 2000 Endoplasmic reticulum quality control of oligomeric membrane proteins: topogenic determinants involved in the degradation of the unassembled $\mathrm{Na}, \mathrm{K}-\mathrm{ATPase}$ alpha subunit and in its stabilization by beta subunit assembly. Mol. Biol. Cell, 11(5):1657-72.

Berger, C.L.; Dong, Z.; Hanlon, D.; Bisaccia, E.; and Edelson, R.L. 1997 A lymphocyte cell surface heat shock protein homologous to the 
endoplasmic reticulum chaperone, immunoglobulin heavy chain binding protein BIP. Int. J. Cancer, 71(6):1077-85.

Cayanis, E.; Russo, J.J.; Wu, Y.S.; and Edelman, I.S. 1992 Serum independence of low $\mathrm{K}+$ induction of Na,K-ATPase: possible role of c-fos. J. Membr. Biol., 125(2):163-70.

Delpino, A.; Pisell,i P.; and Mangano, G. 2002 The 78 kDa glucose-regulated protein (GRP78/BIP) is expressed on the cell membrane, is released into cell culture medium and is also present in human peripheral circulation. Biosci. Rep., 22(3-4):407-20.

Delpino, A.; Piselli, P.; Vismara, D.; Vendetti, S.; and Colizzi, V. 1998 Cell surface localization of the $78 \mathrm{kD}$ glucose regulated protein (GRP 78) induced by thapsigargin. Mol. Membr. Biol., 15(1):21-6.

Eakle, K.A.; Lyu, R.M.; and Farley, R.A. 1995 The influence of beta subunit structure on the interaction of $\mathrm{Na}+/ \mathrm{K}(+)$-ATPase complexes with $\mathrm{Na}+\mathrm{A}$ chimeric beta subunit reduces the $\mathrm{Na}+$ dependence of phosphoenzyme formation from ATP. J. Biol. Chem., 270(23):13937-47.

Ellis, R.J.; van der Vies, S.M.; and Hemmingsen, S.M. 1989 The molecular chaperone concept. Biochem. Soc. Symp., 55:145-53.

Fernandez, P.M.; Tabbara, S.O.; Jacobs, L.K.; Manning, F.C.; Tsangaris, T.N.; Schwartz, A.M.; Kennedy, K.A.; and Patierno, S.R. 2000 Overexpression of the glucose-regulated stress gene GRP78 in malignant but not benign human breast lesions. Breast Cancer. Res. Treat., 59(1):15-26. 
Gething, M.J. 1999 Role and regulation of the ER chaperone BiP. Semin. Cell Dev. Biol., 10(5):465-72.

Gorvel, J.P.; Chavrier, P.; Zerial, M.; and Gruenberg, J. 1991 rab5 controls early endosome fusion in vitro. Cell, 64(5):915-25.

Gottardi, C.J. and M. J. Caplan 1993 Delivery of $\mathrm{Na}+, \mathrm{K}(+)-A T P a s e$ in polarized epithelial cells. Science, 260(5107):552-4; discussion, 554-6.

Gottardi, C.J.; Dunbar, L.A.; and Caplan, M.J. 1995 Biotinylation and assessment of membrane polarity: caveats and methodological concerns. Am. J. Physiol., 268(2 Pt 2):F285-95.

Haas, I.G. 1994 BiP (GRP78), an essential hsp70 resident protein in the endoplasmic reticulum. Experientia, 50(11-12):1012-20.

Haas, M.; Wang, H.; Tian, J.; and Xie, Z. 2002 Src-mediated inter-receptor crosstalk between the $\mathrm{Na}+/ \mathrm{K}+-\mathrm{ATPase}$ and the epidermal growth factor receptor relays the signal from ouabain to mitogen-activated protein kinases. J. Biol. Chem., 277(21):18694-702.

He, H.; McColl, K.; and Distelhorst, C.W. 2000 Involvement of c-Fos in signaling grp78 induction following ER calcium release. Oncogene, 19(51):5936-43.

Huang, L.; Li, H.; and Xie, Z. 1997 Ouabain-induced hypertrophy in cultured cardiac myocytes is accompanied by changes in expression of several late response genes. J. Mol. Cell Cardiol., 29(2):429-37.

Joannidis, M.; Cantley, L.G.; Spokes, K.; Stuart-Tilley, A.K.; Alper, S.L.; and Epstein, F.H. 1997 Modulation of c-fos and egr-1 expression in the 
isolated perfused kidney by agents that alter tubular work. Kidney Int., 52(1):130-9.

Jorgensen, J.R.; Houghton-Larsen, J.; Jacobsen, M.D.; and Pedersen, P.A. 2003 Amino acids in the TM4-TM5 loop of Na,K-ATPase are important for biosynthesis. Ann N Y Acad. Sci., 986:369-77.

Lee, A.S. 2001 The glucose-regulated proteins: stress induction and clinical applications. Trends Biochem. Sci., 26(8):504-10.

Li, W.W.; Alexandre, S.; Cao, X.; and Lee, A.S. 1993 Transactivation of the grp78 promoter by Ca2+ depletion. A comparative analysis with A23187 and the endoplasmic reticulum $\mathrm{Ca}(2+)$-ATPase inhibitor thapsigargin. J. Biol. Chem., 268:12003-9.

Lingrel, J.B.; Van Huysse, J.; O'Brien, W.; Jewell-Motz, E.; and Schultheis, P.1994 Na,K-ATPase: structure-function studies. Ren. Physiol. Biochem., 17(3-4):198-200.

Liu, H.; Bowes, III, R.C.; van de Water, B.; Sillence, C.; Nagelkerke, J.F.; and Stevens, J.L. 1997 Endoplasmic reticulum chaperones GRP78 and calreticulin prevent oxidative stress, Ca2+ disturbances, and cell death in renal epithelial cells. J. Biol. Chem., 272(35):21751-9.

Liu, J.; Periyasamy, S.M.; Gunning, W.; Fedorova, O.V.; Bagrov, A.Y.; Malhotra, D.; Xie, Z.; and Shapiro, J.I. 2002 Effects of cardiac glycosides on sodium pump expression and function in LLC-PK1 and MDCK cells. Kidney Int., 62(6):2118-25.I 
Liu, J.; Kesiry, R.; Periyasamy, S.M.; Malhotra, D.; Xie, Z.; and Shapiro, J.I. 2004 Ouabain induces endocytosis of plasmalemmal Na/K-ATPase in LLC-PK1 cells by a clathrin-dependent mechanism. Kidney Int., 66(1):227-41

Mote, P.L.; Tillman, J.B.; and Spindler, S.R. 1998 Glucose regulation of GRP78 gene expression. Mech. Ageing Dev., 104(2):149-58.

Multhoff, G. and Hightower, L.E. 1996 Cell surface expression of heat shock proteins and the immune response. Cell Stress Chaperones, 1(3):167-76.

Munro, S. and Pelham, H.R. 1987A C-terminal signal prevents secretion of luminal ER proteins. Cell, 48(5):899-907.

Nakagawa, T.; Zhu, H.; Morishima, N.; Li, E.; Xu, J.; Yankner, B.A.; and Yuan, J. 2000 Caspase-12 mediates endoplasmic-reticulum-specific apoptosis and cytotoxicity by amyloid-beta. Nature, 403(6765):98-103.

Nakagawa, Y.; Rivera, V.; and Larner, A.C. 1992 A role for the Na/K-ATPase in the control of human c-fos and c-jun transcription. J. Biol. Chem. 267(13):8785-8 .

Orlov, S.N.; Thorin-Trescases, N.; Kotelevtsev, S.V.; Tremblay, J. and Hamet, P. 1999 Inversion of the intracellular $\mathrm{Na}+/ \mathrm{K}+$ ratio blocks apoptosis in vascular smooth muscle at a site upstream of caspase-3. J. Biol. Chem., 274(23):16545-52.

Peng, M.; Huang, L.; Xie, Z.; Huang, W.H.; and Askari, A. 1996 Partial inhibition of $\mathrm{Na}+/ \mathrm{K}+-\mathrm{ATPase}$ by ouabain induces the $\mathrm{Ca} 2+-$ dependent expressions of early-response genes in cardiac myocytes. J. Biol. Chem., 271(17):10372-8. 
Rao, R.V.; Peel, A.; Logvinova, A.; del Rio, G.; Hermel, E.; Yokota, T.; Goldsmith, P.C.; Ellerby, L.M.; Ellerby, H.M.; and Bredesen, D.E. 2002 Coupling endoplasmic reticulum stress to the cell death program: role of the ER chaperone GRP78. FEBS. Lett., 514(2-3):122-8.

Reddy, R.K.; Mao, C.; Baumeister, P.; Austin, R.C.; Kaufman, R.J., and Lee, A.S. 2003 Endoplasmic reticulum chaperone protein GRP78 protects cells from apoptosis induced by topoisomerase inhibitors: role of ATP binding site in suppression of caspase-7 activation. J. Biol. Chem., 278(23):20915-24.

Rodrigues Mascarenhas, S.; Echevarria-Lima, J.; Fernandes dos Santos, N.; and Rumjanek, V.M. 2003 CD69 expression induced by thapsigargin, phorbol ester and ouabain on thymocytes is dependent on external Ca2+ entry. Life Sci., 73(8):1037-51.

Sorkin. A.; McKinsey, T.; Shih, W.; Kirchhausen, T.; and Carpenter, G. 1995 Stoichiometric interaction of the epidermal growth factor receptor with the clathrin-associated protein complex AP-2. J. Biol. Chem., 270(2):619-25.

Stoddart, A.; Dykstra, M.L.; Brown, B.K.; Song, W.; Pierce, S.K.; and Brodsky F.M. 2002 Lipid rafts unite signaling cascades with clathrin to regulate BCR internalization. Immunity, 17(4):451-62.

Sweadner, K.J. 1989 Isozymes of the Na+/K+-ATPase." Biochim. Biophys. Acta., 988(2):185-220.

Takemoto, H.; Yoshimori, T.; Yamamoto, A.; Miyata, Y.; Yahara, I.; Inoue. K.; and Tashiro, Y.1992 Heavy chain binding protein (BiP/GRP78) and endoplasmin are exported from the endoplasmic reticulum in rat exocrine 
pancreatic cells, similar to protein disulfide-isomerase. Arch. Biochem. Biophys., 296(1):129-36.

Taurin, S.; Dulin, N.O.; Pchejetski, D.; Grygorczyk, R.; Tremblay, J.; Hamet, P.; and Orlov, S.N. 2002a c-Fos expression in ouabain-treated vascular smooth muscle cells from rat aorta: evidence for an intracellular-sodiummediated, calcium-independent mechanism. J. Physiol., 543(Pt 3):835-47. Taurin, S.; Seyrantepe, V.; Orlov, S.N.; Tremblay, T.L.; Thibault, P.; Bennett, M.R.; Hamet, P.; and Pshezhetsky, A.V. 2002b Proteome analysis and functional expression identify mortalin as an antiapoptotic gene induced by elevation of $[\mathrm{Na}+] \mathrm{i} /[\mathrm{K}+] \mathrm{i}$ ratio in cultured vascular smooth muscle cells. Circ. Res., 91(10):915-22.

Villa, A.; Podini, P.; Clegg, D.O.; Pozzan, T.; and Meldolesi, J. 1991 Intracellular $\mathrm{Ca} 2+$ stores in chicken Purkinje neurons: differential distribution of the low affinity-high capacity $\mathrm{Ca} 2+$ binding protein, calsequestrin, of Ca2+ ATPase and of the ER lumenal protein, Bip. J. Cell Biol., 113:779-91.

Wiest, D.L., and Bhandoola, A. 1997 Incomplete endoplasmic reticulum (ER) retention in immature thymocytes as revealed by surface expression of "ER-resident" molecular chaperones. Proc. Natl. Acad. Sci U S A, 94(5):1884-9.

Xiao, G.; Chung, T.F.; Pyun, H.Y.; Fine, R.E.; and Johnson, R.J. 1999 KDEL proteins are found on the surface of NG108-15 cells. Brain Res. Mol. Brain Res., 72(2):121-8. 
Yang, G.H.; Li, S.; and Pestka, J.J. 2000 Down-regulation of the endoplasmic reticulum chaperone GRP78/BiP by vomitoxin (Deoxynivalenol). Toxicol. Appl. Pharmacol., 162(3):207-17.

Yu, Z.; Luo, H.; Fu, W.; and Mattson, M.P. 1999 The endoplasmic reticulum stress-responsive protein GRP78 protects neurons against excitotoxicity and apoptosis: suppression of oxidative stress and stabilization of calcium homeostasis. Exp. Neurol., 155(2):302-14.

Zhou, X.; Jiang, G.; Zhao, A.; Bondeva, T.; Hirszel, P.; and Balla, T. 2001 Inhibition of Na,K-ATPase activates PI3 kinase and inhibits apoptosis in LLC-PK1 cells. Biochem. Biophys. Res. Commun., 285(1):46-51. 


\begin{abstract}
We have demonstrated that ouabain causes dose- and time-dependent decreases both in ${ }^{86} \mathrm{Rb}$ uptake and plasmalemmal Na/K-ATPase content of LLCPK1 cells (Liu et al., 2002). This phenomenon is related to ouabain-induced endocytosis of plasmalemmal Na/K-ATPase in LLC-PK1 Cells by a clathrindependent mechanism (Liu et al., 2004). GRP78/BiP is a resident protein of the endoplasmic reticulum (ER) and acts as a molecular chaperone. Recently, several studies have shown GRP78/BiP is also expressed on the cell surface and forms heterogeneous, high molecular weight complexes with other proteins. To identify the proteins that are possibly involved in ouabain-induced endocytosis of the $\mathrm{Na} / \mathrm{K}$ ATPase in LLC-PK1 cells, we separated and identified endosomal proteins by 2D gel electrophoresis and MS/MS from both control and ouabain-treated LLC-PK1 cells. GRP78/BiP was identified by MS/MS as one of several up-regulated proteins and confirmed by Western Blot. Interestingly, GRP78/BiP was significantly upregulated in both early and late endosomes in response to ouabain treatment. By using a cell surface protein biotinylation technique to isolate the cell surface membrane proteins, we found that GRP/BiP is expressed on the cell surface of LLC-PK1 cells and down-regulated in a time-dependent manner in response to ouabain. By comparing the cellular redistribution, our data suggest that both the Na/K-ATPase a-1 subunit and GRP78/BiP follow the same pattern in response to ouabain.
\end{abstract}

